\title{
The Effect of Mindful Learning on Students' Writing Competency
}

\author{
Made Julio Saputra ${ }^{1 *}$, Kadek Sonia Piscayanti ${ }^{2}$, Dewa Ayu Eka Agustini ${ }^{3}$ \\ ${ }^{123}$ English Language Education, Ganesha University of Education, Singaraja, Indonesia \\ e-mail: made.julio.saputra@undiksha.ac.id sonia.piscayanti@undiksha.ac.id eka.agustini@undiksha.ac.id
}

\begin{abstract}
Students' writing competency, teacher's strategy and engagement in writing process is very crucial. The strategy of teaching writing should not only focus on language aspects but also should help the students in developing their critical thinking and problem solving skill. The current study investigated the effect of mindful learning on students' writing comptency. This study was an experiment study with posttest only control group design. 71 EFL students were involved in this study. In collecting the data, this study used writing competency test and rubric for assessing. The collected data were analzyed using descriptive and inferential statistics. The result of descprtive statistics showed that the mean score of writing competency of experiment group (82.25) was higher than the control group (78.67). The result of effect size test showed a medium effect (.68). Thus, it can be concluded that mindful learning significantly affects students' writing competency.
\end{abstract}

Keywords: Mindful Learning, Writing, EFL

\section{Introduction}

Human resources are required to have the ability or skills that can encourage them to progress and continue to develop. In the current era, one must have 21 st century skills. Skills in the 21st century include (a) critical thinking and problem solving, (b) communication (c) collaboration, and (d) creativity and innovation (Bishop, 2018). Someone must possess these abilities in order to compete with the outside world (Afandi et al., 2019; Boholano, 2017; Jan, 2017). In addition, proficiency in using English as an international language is very important in order to be able to compete with world citizens. English language skills are the main skill that someone needs to master in addition to competing, it can also be used to build international networks (Clement \& Murugavel, 2019).

The ability to use English will also be an added value for someone in finding a job and supporting a career (Lauder, 2008). The policy for the application of English as a subject has been implemented since the junior high school level in Indonesia. However, the results of the National Examination in English as a parameter of the success of English education and teaching show unsatisfactory results, especially in Bali. For three years $(2017,2018,2019)$ it turned out that there were still many students in the moderate mastery category (score range 4.50 - 5.49) and less (score range 4.50 - 5.49).

Internationally, the Indonesian students' English skill is still categorized low. Based on the result of English Proficiency Index (EPI) conducted by international education company, (Yasmine, 2016) reported that Indonesia is ranked 32nd out of 72 countries in 2016 with a score of 52.91, the study put Indonesia below Vietnam, which ranked 31st and fell under the Moderate Proficiency Band category. Surprisingly, Indonesia fell seven spots from 32 to 39th out of 80 countries in 2017 (Valentina, 2017). In the following year, Indonesia's EPI still experienced a decline where in 2018 it was ranked 51 and in 2019 it decreased again to rank 61. The average score in Asian countries is 53.60. According to the report, the score of 52.15 is categorized low proficiency. This indicates that it is necessary to improve the quality of learning and teaching English in order to produce human resources with better English skills.

The low level of students' English skills is certainly influenced by various factors. These factors arise both internally and externally. Internally, the factors of study habits, motivation, anxiety and self-efficacy greatly influence the success of students in mastering English (Badia et al., 2016; Balta, 2018; Fareed et al., 2016; Mahmoudi \& Mahmoudi, 2015; Mitsalina, 2015;

\footnotetext{
${ }^{*}$ Corresponding author.

Received 14 June 2020; Accepted 18 September 2020; Available online 01 December 2020 (C) 2020 JPI. All Rights Reserved
} 
Riswanto \& Aryani, 2017; Torres \& Turner, 2016). Externally, factors such as curriculum, teaching strategies by teachers and support from parents really support students in achieving adequate English competency (O. Akbari \& Razavi, 2016; Pei-Shi, 2012; Ratminingsih et al., 2018)

It is widely accepted that mastering a foreign language is a difficult task. Indonesian students do not use English as their daily communication so they have limited time to practice English (Getie, 2020; Souriyavongsa et al., 2013). Besides that, there are four skills should be mastered namely speaking, writing, reading and listening. Among the four skills, writing requires a special intention since it is a productive skill (Golkova \& Hubackova, 2015; Hasibuan, 2013). There are two reasons why writing skill is very important (Langan, 2001). The reasons are that, first, writing ability is a basic need for English learners to support their academic success. English learners are often asked to do written assignment and their English competence can also be seen from their writing performance. Second, English writing skill is a practical need to support their future carrier. Since writing is taught from earlier stage of learning in Indonesia, teachers need to implement effective teaching strategies in order to make the students able to convey their ideas and concept through writing.

In addition to complexity, writing is a very active process that allows writers to write based on words and ideas in making meaning over ideas and topics developed (Anwar \& Ahmed, 2016). Furthermore, writing is the process of thinking to invent ideas, thinking about how to express an idea into a good writing, and arranging the ideas into statement and paragraph clearly (Nunan, 2003). It indicates that the learners are expected to explore the ideas and make them into good paragraph. Besides, writing is both a physical and a mental act. It is the physical act of committing words or ideas to some medium, whether it is an object or a symbol or an email message. Evidently many studies have found that students encounter many difficulties in the process of making a writing (Fareed et al., 2016; Okumuş, 2019; Siddiqui, 2020). The difficulty is found in the lack of students' ability to develop ideas, grammar and the ability to compose coherence sentences. (Ariyanti, 2016; Rahmatunisa, 2014; Tanyer, 2015; Toba et al., 2019). In general, writing problems include linguistic, psychological, cognitive and pedagogical (Fareed et al., 2016; Haider, 2012). The difficulties cause students to be unable to express their ideas or thoughts in English (Ratminingsih et al., 2018; Torres \& Turner, 2016). Furthermore, the low ability to write also characterizes the lack of critical thinking skills and literacy skills (Mostafa \& Crossley, 2020; Sheldon, 2011)

In addition, the teacher is also a factor that determines the success of learning to write. Many teachers still use traditional approaches such as translation and drilling which have been studied as ineffective in the 21st century learning era (Boholano, 2017; Zafari, 2019). Many of the strategies used in teaching writing focus solely on language aspects such as grammar and vocabulary (Cheung, 2018; Dirgeyasa, 2016). In fact, a writing consists of many components. Teachers are expected to implement strategies that place students as the focus of learning so that students become independent and have responsibility for the learning process (Handayani, 2017; Santosa, 2017). The strategies should be also helping the students to develop their critical thinking and problem solving skill (Changwong et al., 2018; Matthee \& Turpin, 2019).

Teachers should see writing as a process. In the writing process, students go through several stages (Bayat, 2014; Carolan \& Kyppö, 2015; Faraj, 2015; H. Wang, 2018). Commonly those stages are prewriting, drafting, editing, revising, and publishing (Bayat, 2014). In prewriting stage, ideas are collected, and the topic and target reader are determined (Mogahed, 2015). During the drafting stage, specified ideas are put on paper. Ideas and the organization are addressed again in the revision stage (P. Wang, 2015). In the editing stage, mistakes in logical coherence among sentences and paragraphs are corrected. Finally, in the publishing stage, the produced text is shared with others. The process approach emphasizes the writing stage rather than the final result. In this way, students have the opportunity to improve the quality of their writing by looking at the edits and revisions given by either the teacher or their peers (Cheung, 2018; Ningsih, 2016; Panavelil, 2015). Therefore, teachers need to emphasize appropriate writing teaching strategies by focusing on the process. 
One strategy that can be used by teachers is mindful learning. The concept of mindfulness is rooted in Buddhist philosophy but now has grown both practically and theoretically in the realm of modern Psychology (Tuyen, 2015). Mindfulness is the consciousness arising from giving attention to a present experience intentionally and without judgment to be able to respond with acceptance (Kabat-zinn, 2003; Kolb, 2009). The word mindfulness itself can be defined as psychological constructs, psychological processes (being mindful), forms of psychotherapy, or forms of exercise that can shape the condition of mindfulness (Pagnini \& Phillips, 2015; Siegel et al., 2009). Mindfulness deals with the ability of human being to be aware and inquire (Y. Wang \& Liu, 2016).

Mindfulness has been adopted as a learning model. The mindfulness learning model, emphasizes students to have capacity to: (a) observing: the ability to observe and to be aware of thoughts, feelings, perceptions, and sensations; (b) describing: the ability to describe in words; (c) acting with awareness: (d) non-reactivity: non-reactive attitude towards personal experience, and (e) non-judge: attitude without assessment of personal experience (Baer et al., 2006). Those characteristics can encourage the students to build their critical thinking, reflect on their learning, and make use of their learning (Teper et al., 2013; Teper \& Inzlicht, 2013; Y. Wang \& Liu, 2016). Besides, the use of mindful learning helps the students to concentrate and feel motivated during the teaching and learning process (Tuyan \& Kabadayi, 2018).

In the context of teaching English, mindful learning is seen very effective in enhancing students' language skill and furthermore on critical thinking, collaboration, communication and creativity (Davenport \& Pagnini, 2016; Piscayanti, 2018; Rahman, 2017; Y. Wang \& Liu, 2016). Considering Mindful Learning can offer greater benefits upon students' learning achievement and analyzing the characteristic of Mindful Learning itself, it is appropriate to be implemented in teaching writing. Implementing mindful learning in teaching writing is seen very effective because, the learning process is predicted to be more active because it is based on the characteristic of Mindful Learning. It also helps the students to be able increase their participation and motivation during the teaching and learning process (Piscayanti, 2018).

Looking at the benefits that mindful offers to the teaching and learning process, the current study is interested in investigating whether or not the implementation of Mindful Learning gives a significant effect on students' writing competency.

\section{Method}

The current study is an experiment study with posttest only control group design. This study involved an experiment and control group (Cresswell, 2012). The experiment group is taught using mindful learning while the control group is taught with conventional teaching. This study was done at SMA Negeri 1 Kediri which located at Jalan Bingin Ambe, Banjar Anyar, Kediri, Banjar Anyar, Kec. Tabanan, Kabupaten Tabanan, Bali 82123, started from January $20^{\text {th }}-$ April $20^{\text {th }} 2019$. In this design, there are two groups that are chosen randomly. The experimental group is taught using Mindful Learning, while the control group is taught using conventional teaching strategy. At the end of the treatment, both group are given post-test to identify the difference in the writing competency. The result of the treatment is (Q1: Q2). This study involved 71 students (30 Male, 41 female).

In assessing students' writing competency, a rubric for assessing writing was used. The rubric consists of five dimensions of writing namely: content, organization, vocabulary, grammar, and mechanics (Brown, 2004). Each dimension consisted of several indicators and had different weight in scoring. A validity and reliability test were conducted as well to make sure the appropriateness of instrument used in this study. The result of validity from expert judgment show .82 while the result of reliability test show .90. According to Pallant (2016), a valid and reliable instrument can be achieved if the value exceeds .80 . Therefore, the instruments used in this study are valid and reliable.

A descriptive and inferential analysis was conducted in order to analyze the data. A descriptive analysis covers identifying mean score and standard deviation score (Loeb et al., 2017). In inferential analysis, it involves normality, homogeneity, t test. An effect size test was also included to identify the category of effect from the treatment (Fritz et al., 2012). 


\section{Results and Discussion}

The result of data descriptive analysis can be seen in Table 1.

Table 1. The Result of Descriptive Analysis

\begin{tabular}{ccc}
\hline Group & Mean Score & Standard Deviation \\
\hline Experiment & 82.25 & 5.761 \\
Control & 78.67 & 4.708 \\
\hline
\end{tabular}

From the result of descriptive analysis, it can be seen that the mean score of experiment group (82.25) with 5.761 standard deviation is higher than mean score of control group (78.67) with 4.708 standard deviation. The mean difference between experiment and control group is 3.38. To test if the mean difference is significant, a mean comparison test is conducted. The first test conducted was to identify the normality of data. The normality and homogeneity of data is presented in Table 2

Table 2. Normality of Data

\begin{tabular}{ccc}
\hline Group & Kolgomorov-Smirnov & Homogeneity \\
\hline Experiment & .200 & .283 \\
Control & .200 & \\
\hline
\end{tabular}

Based on the table 2 above, by using Kolmogorov-Smirnov, it can be known that the significance value of the experimental class was 0.200 and the significance value of the control group was 0.200 . These significance value exceeded $0.05(p>0.05)$. It means that both classes were normally distributed. It also can be seen that, the significance value (sig.) in homogeneity test based on mean is .283. It can be assumed that the significance value of both experimental and control group exceeded 0.05 ( $p>0.05)$. It means that both groups were homogeneous. Since the data are normal and homogeneous, the $t$ test to identify the significant of mean difference can be run. The result is presented in Table 3.

Table 3. The result of t test

\begin{tabular}{|c|c|c|c|c|}
\hline \multirow[b]{2}{*}{ Group } & \multicolumn{4}{|c|}{ Analysis } \\
\hline & Mean & $\begin{array}{l}\text { Standard } \\
\text { Deviation }\end{array}$ & $\begin{array}{c}\text { Mean } \\
\text { Difference }\end{array}$ & t Test (Sig. 2 tailed) \\
\hline $\begin{array}{l}\text { Experiment } \\
\text { Control }\end{array}$ & $\begin{array}{l}82.25 \\
78.67\end{array}$ & $\begin{array}{l}5.761 \\
4.708\end{array}$ & 3.58 & .005 \\
\hline
\end{tabular}

From the result of data analysis, it can be seen that the result of $t$ test shows that there is a significant mean difference between groups (Sig.2 tailed <.05). A further effect size test shows the mean difference between groups is medium $(d=<0.8)$. The finding showed descriptively that the students who were taught by using Mindful Learning achieved better writing comprehension. It was proven by the result of the post-test that was administrated for both groups. The mean score of the students who were taught by using Mindful Learning (experimental group) was 82.25 , while the mean score of the students who were taught by using conventional writing strategy (control group) was 78.67. In other words, after being analyzed, the students in the experimental group achieved better results than the students in the control group. It showed that Mindful Learning gave a significant effect on students' writing competency. However, the result of effect size test shows a medium significant difference, indicates that besides mindful learning as the strategy of teaching writing, there is another factor that contributing to students' writing competency.

In detail, the experimental group's ability to write English in terms of language components, namely grammar, vocabulary, and other assessed aspects such as content 
organization and mechanics was better than the control group. According to Myhill Watson (2014), grammar is an important aspect in a language production that includes writing and speaking. The correct grammar will lead the reader to capture the message the writer wants to convey (Z. Akbari, 2014; Mart, 2013; Olinghouse \& Wilson, 2013; Qosayere, 2015). Students in the experimental group seem to use varied vocabulary. This indicates that they have a rich vocabulary. Students with rich vocabulary will be able to use the right words to represent the meaning or message to be conveyed to readers (Lane \& Allen, 2010; Solati-dehkordi \& Salehi, 2016; Viera, 2018). Students in experimental group showed a better content organization. In writing, a good content organization will make a good flow writing so that readers will more easily grasp the message (Ruegg \& Sugiyama, 2013; Tosuncuoğlu, 2018).

The findings supported the research conducted by Wang and Liu (2016) who found that activity helped those students focus on their work and reflect on their reading and writing experience. It is also supported by Ager, Bucu, Albrecht, and Cohen, (2014) who found that mindful learning can benefit the whole person, including the mind, body, and emotions. It can positively affect the well-being of both teaching staffs and students in school because it has been shown to reduce stress, support the development of core character traits such as empathy and awareness of self and others, and improve the happiness and well-being of teaching staffs and students. Besides, it also helps to focus the attention of both the mind and body, and assist with conflict resolution.

Judging from the results obtained in the control group, their writing competency is far from being compared to the experimental group. Teaching and learning process in the control group uses conventional methods such as lecturing which is proven to be less effective in improving students' writing skills. These results were also obtained from research conducted by (Al-sohbani, 2016) who found that conventional learning strategies had no significant effect on students' English skills. Learning English requires an active approach so that students are involved in the learning process (Demirci, 2017; Demirci \& Yavaslar, 2018; Rahayu, 2018). Active learning will give students the opportunity to use English so that they will acquire language knowledge automatically.

Theoretically, Mindful Learning is a conventional approach with a student centered approach that accommodates openness to new information and learning awareness, so that students' creativity and mindset are more developed (Noone et al., 2016; Rahman, 2017; Y. Wang \& Liu, 2016). Mindful Learning is learning where students find and build their own new knowledge and skills to understand, where the subject matter is delivered with students' own experiences, creating group learning makes students able to discuss, work together, and help each other with other friends so learning will be more fun and enjoyable. (Davenport \& Pagnini, 2016; Noone et al., 2016). The implementation of mindful learning in this study helped the students to pay their attention towards the learning process. Mindful Learning in this study gave benefit as a deterrent to the decline in the ability to concentrate student learning even in ineffective conditions. Previous studies had identified that using mindful learning in the classroom helps the students to train the ability to concentrate, the ability to calm down, increase self-esteem, self-confidence, and motivation (Ghanizadeh et al., 2019; Morgan, 2019). The activity in mindful learning creates a focus learning process, encourage and motivate the students in learning, and trains students' social-emotional awareness (Davenport \& Pagnini, 2016; Y. Wang \& Liu, 2016). Learning to focus can help increase their attention and develop greater patience and endurance for each activity. The students will also be free from automatic pilot conditions.

The implementation of Mindful Learning in this study led the students to see a situation from more than one perspective. Mindful Learning allowed students to be actively involved in the learning process by searching for and finding their own written review concepts based on students' own opinions. It allowed students to use their thinking skills to obtained material from various sources such as books, their own experiences, and material from the teacher. It involved the students in digging up the subject matter information. Implementing Mindful Learning required students to move using their minds. Students tried to get as much information about the subject matter as possible and then share it in the discussion before pouring it into the writing text. In addition, Mindful Learning was able to attract students' 
attention in learning, able to arouse students' emotions and passion in expressing opinions, and able to stimulate students' critical thinking. This happened because in the learning process the students found out their own ideas from many sources and perspective, so that it was able to create a new atmosphere and enjoy learning. In line with that, Y. Wang and Liu (2016) found that mindful helps students to generate new thoughts and become aware of their thinking; mindfulness facilitates their learning process, cultivates creativity and intelligence; mindful cooperative learning provides students with an opportunity to discover their awareness, learn from others, reflect and think critically.

During the implementation of mindful learning, students were involved in discussion activities. They tried to get as much information about the subject matter as possible and then share it in the discussion before pouring it into the writing text. It was identified that the students were able to express their opinions and give comments and suggestions for other. These activities engages students' critical thinking skill, problem solving skill and creates an active and reflective learning atmosphere, which are very essential in teaching and learning process (Noone et al., 2016; Oakley, 2018; Wen et al., 2013). The implementation of mindful learning in the classroom in addition to improving student competency and learning outcomes is also useful for enhancing 21st century skills (Davenport \& Pagnini, 2016; Teper et al., 2013; Teper \& Inzlicht, 2013). It can be said that mindful learning applications in the learning process make students active. According to the results of research conducted by (Lin, 2020), mindful learning provides engagement to the students learning process. This engagement is important to make students motivated and eager to learn (Marius et al., 2018). The use of mindful learning in this study greatly affects students' awareness of their writing process (Kong et al., 2014). In this way, students know their mistakes and shortcomings during writing process. This can also be said to be a student's self-evaluation of their writing ability. Self-evaluation in a writing process is very important in order to improve the quality of student writing (Bing, 2016; Ratminingsih et al., 2018).

Opinions that were expressed in the learning could make it easier for students to write review paragraph. Then students arranged several questions for the answers they want to know, so from these questions the writing goal was formed. After completion, students were required to answer the question that was previously formulated by the teacher through writing activity. Before arranging the answers into a summary to make a text, the students were asked to share their answer in a group. They share their own perspective to others.

In the mindful discussion, the students' thinking and understanding went deeper and they expressed their thoughts in a more accurate way that they agreed upon. With this, students felt facilitated and motivated in the learning process so that the ability of students to write paragraphs of the review increases. Carrying out the discussion before writing the review text will make it easier for students to compile the review paragraph itself. Besides, in Mindful Learning, the students also were allowed to think freely but remain in the guidance. There was no right or wrong answer of their thought because the opinions of students in Mindful Learning were not absolute because they were all based on thought.

The learning process and teaching of writing today must focus on students. Conventional strategies that are currently used are often not suitable for 21 st century learning (Boholano, 2017; Handayani, 2017; Sudirman, 2019). The reason teachers continue to use conventional teaching methods such as lectures and drills is because these methods are easy to apply in the classroom (Mokhtar, 2016). The English teacher mainly needs to take an authentic approach and strategy so that students get the opportunity and experience that suits real conditions.

\section{Conclusion and suggestions}

There is a significant difference in writing competency between the students who are taught by using Mindful Learning and the students who were taught by using conventional writing strategy. The finding showed descriptively that the students who were taught by using Mindful Learning achieved better writing comprehension. 


\section{References}

Afandi, A., Sajidan, S., Akhyar, M., \& Suryani, N. (2019). Development frameworks of the Indonesian partnership $21 \mathrm{st}$-century skills standards for prospective science teachers: A Delphi study. Jurnal Pendidikan IPA Indonesia, 8(1), 89-100. https://doi.org/10.15294/jpii.v8i1.11647

Ager, K., Bucu, A., Albrecht, N., \& Cohen, M. (2014). Mindfulness in Schools Research Project: Exploring Teachers' and Students' Perspectives - Preliminary Report. https://doi.org/10.13140/2.1.1598.1760

Akbari, O., \& Razavi, A. (2016). Using authentic materials in the foreign language classrooms: Teachers ' perspectives in EFL classes. International Journal of Research Studies in Education, 5(2), 105-116.

Akbari, Z. (2014). The Role of Grammar in Second Language Reading Comprehension: Iranian ESP Context. International Conference on Current Trends in ELT The, 122126. https://doi.org/10.1016/j.sbspro.2014.03.397

Al-sohbani, Y. A. Y. (2016). An Investigation of the Reasons Behind the Weaknesses in English Among Public Secondary School Leavers. Journal of Teaching and Teacher Education, 4(2), 41-51. https://doi.org/10.12785/jtte/040105

Anwar, M. N., \& Ahmed, N. (2016). Difficulties in Learning Writing Skills in Second Language. Lahore, 28(4), 735-739.

Ariyanti. (2016). The Teaching of EFL Writing in Indonesia. Dinamika IImu, 16(2), 263-277. https://doi.org/10.21093/di.v16i2.274

Badia, A., Garcia, C., \& Meneses, J. (2016). Approaches to teaching online : Exploring factors influencing teachers in a fully online university. British Journal of Educational Technology, 48(6), 1-15. https://doi.org/10.1111/bjet.12475

Baer, R., Smith, G. T., Hopkins, J., Krietemeyer, J., \& Toney, L. (2006). Using Self-Report Assessment Methods to Explore Facets of Mindfulness. Assessment, 13(1), 27-45. https://doi.org/10.1177/1073191105283504

Balta, E. E. (2018). The Relationships Among Writing Skills, Writing Anxiety and Metacognitive Awareness. Journal of Education and Learning, 7(3), 233-241. https://doi.org/10.5539/jel.v7n3p233

Bayat, N. (2014). The Effect of the Process Writing Approach on Writing Success and Anxiety. Educational Sciences: Theory \& Practice, 14(3), 1133-1142. https://doi.org/10.12738/estp.2014.3.1720

Bing, X. U. (2016). Writing of Chinese College Students. Journalism and Mass Communication, 6(2), 91-107. https://doi.org/10.17265/2160-6579/2016.02.005

Bishop, J. (2018). Partnership for 21st Century Skills.

Boholano, H. (2017). Smart Social Networking: 21st Century Teaching and Learning Skills. Research in Pedagogy, 7(1), 21-29. https://doi.org/10.17810/2015.45

Brown, D. (2004). Language Assessment: Principles and Classroom Practices. San Fransisco State University.

Carolan, F., \& Kyppö, A. (2015). Teaching process writing in an online environment. In J. Jalkanen, E. Jokinen, \& P. Taalas (Eds.), Voices of pedagogical development Expanding, enhancing and exploring higher education language learning (pp. 13-30). Research-publishing.net. doi:10.14705/rpnet.2015.000285. https://doi.org/10.14705/rpnet.2015.000285

Changwong, K., Sukkamar, A., \& Sisan, B. (2018). Critical thinking skill development: Analysis of a new learning management model for Thai high schools. Journal of International 
Studies, 11(2), 37-48. https://doi.org/10.14254/2071-8330.2018/11-2/3

Cheung, Y. L. (2018). Teaching Writing. In W. A. Renandya \& H. P. Widodo (Eds.), English Language Teaching Today: Building a Closer Link Between Theory and Practice (Issue August 2016). Springer International. https://doi.org/10.1007/978-3-319-38834-2

Clement, A., \& Murugavel, T. (2019). English for the Workplace: The Importance of English Language Skills for Effective Performance. The English Classroom, 20(1), 1-15.

Cresswell, J. W. (2012). Educational Research. Pearson.

Davenport, C., \& Pagnini, F. (2016). Mindful Learning: A Case Study of Langerian Mindfulness in Schools. Psycho, 7(1372), 1-5. https://doi.org/10.3389/fpsyg.2016.01372

Demirci, C. (2017). The Effect of Active Learning Approach on Attitudes of 7 th Grade Students. International Journal of Instruction, 10(4), 129-144. https://doi.org/10.12973/iji.2017.1048a

Demirci, C., \& Yavaslar, E. (2018). Active learning: let's make them a song. Cypriot Journal of Educational Sciences, 13(3), 288-298.

Dirgeyasa, I. W. (2016). Genre-Based Approach: What and How to Teach and to Learn Writing. English Language Teaching, 9(9), 45-51. https://doi.org/10.5539/elt.v9n9p45

Faraj, A. K. A. (2015). Scaffolding EFL Students' Writing through the Writing Process Approach. Journal of Education and Practice ISSN, 6(13), 131-141.

Fareed, M., Ashraf, A., \& Bilal, M. (2016). ESL Learners' Writing Skills: Problems, Factors and Suggestions. Journal of Education and Social Sciences, 4(2), 81-92. https://doi.org/10.20547/jess0421604201

Fritz, C. O., Morris, P. E., \& Richler, J. J. (2012). Effect Size Estimates: Current Use , Calculations, and Interpretation. Journal of Experimental Psychology: Genera, 141(1), 2-18. https://doi.org/10.1037/a0024338

Getie, A. S. (2020). Factors affecting the attitudes of students towards learning English as a foreign language. Cogent Education, 7(1), 1-37. https://doi.org/10.1080/2331186X.2020.1738184

Ghanizadeh, A., Makiabadi, H., \& Navokhi, S. A. (2019). Relating EFL university students' mindfulness and resilience to self-fulfilment and motivation in learning. Issues in Educational Research, 29(3), 695-714.

Golkova, D., \& Hubackova, S. (2015). Productive Skills in Second Language Learning. Procedia - Social and Behavioral Sciences, 143, 477-481. https://doi.org/10.1016/j.sbspro.2014.07.520

Habibi, A., \& Sofwan, M. (2016). English Teaching Implementation in Indonesia Pesantresn: Teachers' Demotivation Factors. Indonesian Journal of English Teaching, 5(2), 200 213. https://doi.org/10.15642/ijet.2016.5.2.199-213

Haider, G. (2012). An Insight Into Difficulties Faced By Pakistani Student Writers : Implications for Teaching of Writing. Journal of Educational and Social Research, 2(3), 17-28. https://doi.org/10.5901/jesr.2012.v2n3p17

Handayani, N. (2017). Becoming the Effective English Teachers in the 21st Century: What Should Know and What Should Do? 1st English Language and Literature International Conference (ELLIC), 156-164.

Hasibuan, K. (2013). Teaching Writing as Productive Skills. Language Development Centre, $4(2), 1-22$.

Jan, H. (2017). Teacher of 21 st Century: Characteristics and Development Teacher of 21 st Century: Characteristics and Development. Research on Humanities and Social 
Sciences, 7(9), 50-54.

Kabat-zinn, J. (2003). Mindfulness-Based Interventions in Context: Past, Present, and Future. Clinical Psychology: Science and Practice, 10(2), 144-156. https://doi.org/10.1093/clipsy/bpg016

Kolb, D. (2009). Mindfulness and Experiential Learning. OD Practitioner, 41(3), 13-18.

Kong, F., Wang, X., \& Zhao, J. (2014). Dispositional mindfulness and life satisfaction: The role of core. Personality and Individual Differences, 56, 165-169. https://doi.org/10.1016/j.paid.2013.09.002

Lane, H. B., \& Allen, S. A. (2010). The Vocabulary-Rich Classroom : Modeling Sophisticated Word Use to Promote Word Consciousness and Vocabulary Growth. The Reading Teacher, 63(5), 362-370. https://doi.org/10.1598/RT.63.5.2

Langan, J. (2001). College Writing Skills (6th ed.). The Mc Graw Hill Companies.

Lauder, A. (2008). The Status and Function of English in Indonesia: A Review of Key Factors. Makara, 12(1), 9-20.

Lin, Y. (2020). The Interrelationship Among Psychological Capital, Mindful Learning, and English Learning Engagement of University Students in Taiwan. SAGE Open Journal, 10(1), 1-12. https://doi.org/10.1177/2158244020901603

Loeb, S., Dynarski, S., Mcfarland, D., Morris, P., Reardon, S., \& Reber, S. (2017). Descriptive analysis in education: A guide for researchers (Issue March).

Mahmoudi, S., \& Mahmoudi, A. (2015). Internal and External Factors Affecting Learning English as a Foreign. International Journal of Language and Linguistics, 3(5), 313-322. https://doi.org/10.11648/j.ijll.20150305.16

Marius, P., Sèna, U. O., \& Kodjo, T. (2018). Examining the Impacts of Cartoons on Motivating EFL Beginner Students to Speak English Language in Beninese Secondary Schools: The Case Study of Some Secondary Schools in the Atlantic Region. American Scientific Research Journal for Engineering, Technology, and Sciences, 50(1), 155180.

Mart, Ç. T. (2013). Teaching Grammar in Context: Why and How ? Theory and Practice in Language Studies, 3(1), 124-129. https://doi.org/10.4304/tpls.3.1.124-129

Matthee, M., \& Turpin, M. (2019). Teaching Critical Thinking , Problem Solving and Design Thinking: Preparing IS Students for the Future Machdel Matthee. Journal of Information Systems Education, 30(4), 242-252.

Mitsalina, E. (2015). Language Teaching Materials and Learner Motivation in Ma'arif Nahdlatul Ulama University Students. English Teaching Journal, 6(1), 32-40.

Mogahed, M. (2015). Planning out pre-writing activities. Academia Journal, 4(3), 60-68. https://doi.org/10.5897//JEL12.120

Mokhtar, F. A. (2016). Rethinking Conventional Teaching In Language Learning And Proposing Edmodo As Intervention: A Qualitative Analysis. Malaysian Online Journal of Educational Technology, 4(2), 22-37.

Morgan, W. J. (2019). Investigating the Effects of Mindfulness Meditation on L2 Learners' SelfEfficacy in an Instructed Foreign Language Context. The University of Alabama.

Mostafa, T., \& Crossley, S. A. (2020). Verb argument construction complexity indices and L2 writing quality: Effects of writing tasks and prompts. Journal of Second Language Writing, 49. https://doi.org/10.1016/j.jslw.2020.100730

Myhill, D., \& Watson, A. (2014). The role of grammar in the writing curriculum: A review of the literature. Child Language Teaching and Therapy, 30(1), 41-62. 


\section{https://doi.org/10.1177/0265659013514070}

Ningsih, S. (2016). Guided Writing to Improve the Students 'Writing Ability of Junior High School Students. EFL Journal, 1(2), 129-140.

Noone, C., Bunting, B., \& Hogan, M. J. (2016). Does Mindfulness Enhance Critical Thinking? Evidence for the Mediating Effects of Executive Functioning in the Relationship between Mindfulness and Critical Thinking. Frontiers in Psychology, 6(2043), 1-16. https://doi.org/10.3389/fpsyg.2015.02043

Nunan, D. (2003). Practical English Language Teaching. McGraw Hill.

Oakley, G. (2018). Early Career Teachers ' Knowledge and Practice in Spelling Instruction: Insights for Teacher Educators. Australian Journal of Teacher Education, 43(12), 5975.

Okumuş, N. (2019). Student perceptions of difficulties in second language writing. Journal of Language and Lingustic Studies, 15(1), 151-157. https://doi.org/10.17263/jlls.547683

Olinghouse, N. G., \& Wilson, J. (2013). The relationship between vocabulary and writing quality in three genres. Reading \& Writing, 26, 45-65. https://doi.org/10.1007/s11145-0129392-5

Pagnini, F., \& Phillips, D. R. (2015). Being mindful about mindfulness. Lancet Psychiatry, 2, 288-289. https://doi.org/10.1016/S2215-0366(15)00041-3

Pallant, J. (2016). SPSS Survival Manual: A Step by Step Guide to Data Analysis Using IBM SPSS. Open University Press.

Panavelil, A. (2015). Methodologies for Effective Writing Instruction in EFL and ESL Classrooms. February. https://doi.org/10.4018/978-1-4666-6619-1.ch008

Pei-Shi, W. (2012). The Effect of Learning Styles on Learning Strategy Use by EFL Learners Weng Pei-Shi. Journal of Social Sciences, 8(2), 230-234.

Piscayanti, K. S. (2018). The power of mindful learning in professional development course. Global Conference on Teaching, Assessment, and Learning in Education (GC-TALE), 42, 1-5.

Qosayere, I. (2015). The Effect of Grammar Correction on Students' Writing. International Interdisciplinary Journal of Education, 4(1), 257-261.

Rahayu, A. S. (2018). Engaging the Students with Styles in EFL Perscpetive. CELTIC: A Journal of Culture, English Language Teaching, Literature \& Linguistics, 3(1), 15-29.

Rahman, M. A. (2017). Writing to Be: Mindful Composition to Promote Writing Transfer. St. Cloud State University.

Rahmatunisa, W. (2014). Problems Faced by Indonesian EFL Learners in Writing Argumentative Essay. Journal of English Education, 3(1), 1-9.

Ratminingsih, N. M., Marhaeni, A. A. I. N., \& Vigayanti, L. P. D. (2018). Self- Assessment: The Effect on Students 'Independence and Writing Competence. International Journal of Inst, 11(3), 277-290.

Riswanto, A., \& Aryani, S. (2017). Learning motivation and student achievement: description analysis and relationships both. The International Journal of Counseling and Education, 2(1), 42-47.

Ruegg, R., \& Sugiyama, Y. (2013). Organization of ideas in writing: what are raters sensitive to ? Language Testing in Asia, 3(8), 1-13. https://doi.org/10.1186/2229-0443-3-8

Santosa, M. H. (2017). Learning approaches of Indonesian EFL Gen Z students in a Flipped Learning context Journal on English as a Foreign Language Learning approaches of Indonesian EFL Gen Z students. Journal on English as a Foreign Language, 7(2), 183- 


\section{8. https://doi.org/10.23971/jefl.v7i2.689}

Sheldon, E. (2011). Rhetorical differences in RA introductions written by English L1 and L2 and Castilian Spanish L1 writers. Journal of English for Academic Purposes, 10(4), 238-251. https://doi.org/10.1016/j.jeap.2011.08.004

Siddiqui, K. A. (2020). Analyzing Factors Influencing the Paragraph Organization in English Language Writing of Intermediate Students. International Journal of Teaching and Learning in Higher Education, 32(1), 99-106.

Siegel, R., Germer, C., \& Olendzki, A. (2009). Mindfulness: What Is It? Where Did It Come From? In F. Didonna (Ed.), Toward a Phenomenology of Mindfulness: Subjective Experience and Emotional Correlates (pp. 17-35). Springer. https://doi.org/10.1007/978-0-387-09593-6

Solati-dehkordi, S. A., \& Salehi, H. (2016). Impact of Explicit Vocabulary Instruction on Writing Achievement of Upper-Intermediate EFL Learners. International Education Studies, 9(4), 141-154. https://doi.org/10.5539/ies.v9n4p141

Souriyavongsa, T., Rany, S., Jafre, M., Abidin, Z., \& Mei, L. L. (2013). Factors Causes Students Low English Language Learning: A Case Study in the National University of Laos. International Journal of English Language Education, 1(1), 179-192. https://doi.org/10.5296/ijele.v1i1.3100

Sudirman. (2019). The 21st-Century Teacher: Teacher's Competence Within the Character Education Framework Towards A Cultural-Oriented Development and Promoting Tolerance. International Education Studies, 12(8), 21-25. https://doi.org/10.5539/ies.v12n8p21

Tanyer, S. (2015). The role of writing and reading self-efficacy in first-year preservice EFL teachers ' writing performance. Procedia - Social and Behavioral Sciences, 199, 3843. https://doi.org/10.1016/j.sbspro.2015.07.484

Teper, R., \& Inzlicht, M. (2013). Meditation , mindfulness and executive control : the importance of emotional acceptance and brain-based performance monitoring. Soc. Cogn. Affect. Neurosci, 8, 85-92. https://doi.org/10.1093/scan/nss045

Teper, R., Segal, Z. V., \& Inzlicht, M. (2013). Current Directions in Psychological Science Inside the Mindful Mind: How Mindfulness. Current Directions in Psychological Science, 22(6), 449-454. https://doi.org/10.1177/0963721413495869

Toba, R., Noor, W., \& Sanu, L. O. (2019). The Current Issues of Indonesian EFL Students ' Writing Skills: Ability, Problem, and Reason in Writing Comparison and Contrast Essay. Dinamika IImu, 19(1), 57-73. https://doi.org/10.21093/di.v19i1.1506

Torres, K. M., \& Turner, J. E. (2016). Students ' foreign language anxiety and self- efficacy beliefs across different levels of university foreign language coursework. Journal of Spanish Language Teaching, 1-17. https://doi.org/10.1080/23247797.2016.1163101

Tosuncuoğlu, I. (2018). Forming a Well Organized Writing Activities. Journal of Education and Training Studies, 6(6), 122-127. https://doi.org/10.11114/jets.v6i6.3111

Tuyan, S., \& Kabadayi, B. (2018). Cultivating Mindfulness in the EFL Classroom: An Exploratory Study. In G. Barkhuizen, A. Burns, D. Kenan, \& M. Wyatt (Eds.), Empowering Teacher- Researchers, Empowering Learners (pp. 67-73). IATEFL.

Tuyen, L. (2015). An Investigation into the Use of the Course Book for Non-English Major Students at the Tertiary Level. International Journal on Studies in English Language and Literature, 3(6), 14-30.

Valentina, J. (2017, December). Indonesia falls in 2017 English proficiency index. Jakarta Post.

Viera, R. T. (2018). Vocabulary knowledge in the production of written texts: a case study on 
EFL language learners. Revista Tecnológica, 30(3), 89-105.

Wang, H. (2018). " Teaching is learning ": creating a meaningful English L2 writing class with service-learning writing class with service-learning. Pedagogies: An International Journal, 1-16. https://doi.org/10.1080/1554480X.2018.1440561

Wang, P. (2015). Effects of an Automated Writing Evaluation Program : Student Experiences and Perceptions. Electronic Journal of Foreign Language Teaching, 12(1), 79-100.

Wang, Y., \& Liu, C. (2016). Cultivate Mindfulness: A Case Study of Mindful Learning in an English as a Foreign Language Classroom. The IAFOR Journal of Education, 4(2), 142-155.

Wen, M., Butler, L. T., \& Koutstaal, W. (2013). Improving insight and non-insight problem solving with brief interventions. British Journal of Psychology, 104, 97-118. https://doi.org/10.1111/j.2044-8295.2012.02107.x

Yasmine, D. (2016, December). Indonesia Falling Behind Vietnam in English Proficiency: Survey. Jakarta Globe.

Zafari, N. M. K. (2019). 21 st Century Teaching Integrating Innovation in a Traditional Classroom. SSRN Electronic Journal. https://doi.org/10.2139/ssrn.3375460 